\title{
The effect of ice phenology exerted on submerged macrophytes through physicochemical parameters and the phytoplankton abundance
}

\author{
Wojciech EJANKOWSKI, ${ }^{*}$ Tomasz LENARD \\ Faculty of Biotechnology and Environment Sciences, The John Paul II Catholic University of Lublin, Konstantynów 1H, 20-708 Lublin, \\ Poland \\ *Corresponding Author: wejan@kul.pl
}

\begin{abstract}
The physicochemical parameters of water, the concentration of chlorophyll-a and the submerged aquatic vegetation (SAV) were studied to evaluate the effects of different winter seasons on the biomass of macrophytes in shallow eutrophic lakes. We hypothesised that a lack of ice cover or early ice-out can influence the physicochemical parameters of water and thus change the conditions for the development of phytoplankton and SAV. The studies were conducted in four lakes of the Western Polesie region in mid-eastern Poland after mild winters with early ice-out (MW, 2011 and 2014) and after cold winters with late ice-out (CW, 2010, 2012 and 2013). The concentrations of soluble and total nitrogen, chlorophyll-a and the TN:TP ratio in the lakes were considerably higher, whereas the concentration of soluble and total phosphorus and water transparency were significantly lower after the MW compared with after the CW. No differences were found in water temperature, reaction and electrolytic conductivity. Low water turbidity linked with low concentration of chlorophyll-a after the CW resulted in increased water transparency and the total biomass of the SAV. The negative effect of the MW on the macrophyte species was stronger on more sensitive species (Myriophyllum spicatum, Stratiotes aloides) compared with shade tolerant Ceratophyllum demersum. Our findings show that the ice cover phenology affected by climate warming can change the balance between phytoplankton and benthic vegetation in shallow eutrophic lakes, acting as a shift between clear and turbid water states. We speculate that various responses of macrophyte species to changes in the water quality after two winter seasons ( $C W$ and $M W$ ) could cause alterations in the vegetation biomass, particularly the expansion of shade tolerance and the decline of light-demanding species after a series of mild winters.
\end{abstract}

Key words: Aquatic vegetation; chlorophyll-a; ice cover; mild and cold winter; climatic effects; eutrophic lakes.

Received: March 2015. Accepted: September 2015

\section{INTRODUCTION}

The current climate warming directly affects the temperature of surface water in lakes and indirectly physicochemical and biological processes related to temperature (Dokulil, 2014). A strong effect of the climate change is observed in winter, when varied meteorological conditions influence the phenology of ice cover on lakes. Mild winters, which are characterised by relatively high mean air temperatures and a short period of ice cover on lakes, are a product of the current climate change. A positive trend in annual air temperature in the Northern Hemisphere causes late ice formation and early ice cover thawing (Magnuson et al., 2000; Livingstone et al., 2010; Peng et al., 2013). The duration of ice cover is non-linearly correlated with air temperature; thus, the trend towards earlier ice break-up is generally stronger in lower than higher latitudes (Weyhenmeyer et al., 2004, 2005). This effect is even stronger in Central Europe (including Poland) compared with Northern Europe. In different regions of Poland, the mean air temperature in some winter and spring months (February, March and May) has increased over the last few decades (Degirmendžić et al., 2004; Kaszewski et al., 2009). In the Polish lowland lakes, this trend causes longer periods of ice-free conditions and much earlier dates of the latest ice break-up - on average, from 0.6 to 0.8 days per year (Marszelewski and Skowron, 2006).

The ice cover influences the environmental conditions in water and the ecological functioning of lakes. It stabilises thermal conditions in water bodies and affects the underwater light climate and water chemistry (e.g., nutrients and dissolved organic carbon concentration), the occurrence of winter fish kill and the production and diversity of phytoplankton and zooplankton (Ohlendorf et al., 2000; Hargeby et al., 2004; Christoffersen et al., 2008; Ejankowski and Lenard, 2015). The increased mixing during ice-free winters can facilitate the alteration of the ecological status of the lake (Livingstone et al., 2010). After mild winters, the nutrient concentration, phytoplankton biomass, water turbidity and temperature are generally higher than after cold winters (Gerten and Adrian, 2000; Weyhenmeyer et al., 2008; Lenard and Wojciechowska, 2013). The earlier thawing of snow and ice can result in the earlier occurrence of the phytoplankton spring bloom (Weyhenmeyer et al., 1999; Laugaste et al., 2010), which determines the light climate for the growth of macrophytes (Blindow, 1992; Asaeda and Bon, 1997). 
The influence of ice phenology on physicochemical parameters and phytoplankton productivity in these waters suggests that there is also a relationship between the duration of ice cover and the abundance of submerged aquatic macrophytes. The expected effect could be restricted to a rather short post-winter period after ice breakup (Gerten and Adrian, 2000; Weyhenmeyer et al., 2008). The early ice thawing could decrease the vegetation biomass as a consequence of increased turbidity and restricted light penetration in the water column. Thus, it could change the balance between phytoplankton and vegetation in shallow eutrophic lakes, as a shift between clear and turbid water states (Wallsten and Forsgren, 1989; Scheffer and van Nes, 2007). However, this effect could be negligible because in temperate lakes, the productivity and biomass of macrophytes considerably increase during the growing season together with light and temperature conditions, reaching the maximum in summer (Westlake, 1965; Asaeda and Bon, 1997; Nikolić et al., 2007).

The concentrations of mineral forms of nutrients, such as, ammonia and nitrate nitrogen or phosphate phosphorus, in lakes are often higher after a mild winter (Weyhenmeyer et al., 2008; Laugaste et al., 2010; Pełechata et al., 2015), which may be related to permanent water mixing during ice-free winters (Lenard and Wojciechowska, 2013). Thus, a larger portion of soluble nutrients may be available for primary producers in the following season and can lead to phytoplankton blooms (Uchmański and Szeligiewicz, 1988). Furthermore, the occurrence of high phytoplankton biomass coupled with high water turbidity after a mild winter may delay the onset of the stratification period (Gerten and Adrian, 2001), which can influence future phytoplankton composition. If the effect of the absence of ice cover on lakes is extended over time, the biomass of many macrophyte populations will be negatively affected during the summer season (Netten et al., 2011). However, this effect can be reversed in lakes with overwintering charophyte meadows, which are able to maintain high water clarity by limiting the development of phytoplankton (Pełechata et al., 2015).
Macrophytes play an important role in the ecological functioning of lakes and reservoirs. They provide habitats and refuge for fish and zooplankton, stabilise sediments and are involved in the nutrient cycling that improves the water transparency (Jeppesen et al., 1998; Madsen et al., 2001; Søndergaard et al., 2003). Aquatic vegetation can inhibit the growth of microalgae by competition for nutrients and by allelopathic effects (Scheffer et al., 1993; Nakai et al., 1999). Thus, changes in macrophyte biomass may influence the aquatic ecosystem in many aspects.

Development of macrophytes is often analysed in the context of rising temperature during the growing season, which is often connected with the current climate change. The results are ambiguous and often related to the amplitude of water temperature (Barko et al., 1982; Rooney and Kalff, 2000; Mckee et al., 2002). Only very few studies have addressed the indirect effects of ice cover duration on the development of submerged vegetation (Hargeby et al., 2004).

In the present study, we analysed the relationship between data on the ice break-up and biomass of submerged macrophytes in eutrophic lakes. We hypothesised that: i) the physicochemical parameters of water and phytoplankton abundance during the growing season are linked to the absence of ice or early ice-out on lakes; ii) macrophyte biomass during the summer season after mild winter is negatively affected by the high water turbidity induced by high phytoplankton abundance.

\section{METHODS}

The studies were conducted from 2010 to 2014 in four lakes, Czarne, Głębokie, Gumienek and Maśluchowskie located near the village of Uścimów in the Western Polesie region (mid-eastern Poland). With 67 lakes, Western Polesie is part of a large geographical region referred to as Polesie and divided between three countries: Poland, Ukraine and Belarus (Kondracki, 2002).

The studied lakes are small, shallow, eutrophic and situated in close proximity (Tab. 1). The lakes have similar susceptibility to changes in thermal conditions of water

Tab. 1. Morphometric characteristics of the studied lakes in the West Polesie region by Wilgat et al. (1991).

\begin{tabular}{|c|c|c|c|c|c|c|c|c|}
\hline \multirow[t]{2}{*}{ Lake } & \multirow[t]{2}{*}{ Coordinates } & \multirow{2}{*}{$\begin{array}{l}\text { Area } \\
\text { (ha) }\end{array}$} & \multirow{2}{*}{$\begin{array}{l}\text { Length } \\
\text { (m) }\end{array}$} & \multirow{2}{*}{$\begin{array}{c}\text { Mean } \\
\text { width (m) }\end{array}$} & \multicolumn{2}{|c|}{ Depth (m) } & \multirow{2}{*}{$\begin{array}{l}\text { Volume } \\
\left(10^{3} \mathrm{~m}^{3}\right)\end{array}$} & \multirow{2}{*}{$\begin{array}{l}\text { Mean slope } \\
\text { inclination }\end{array}$} \\
\hline & & & & & $\max$ & mean & & \\
\hline Czarne & $\begin{array}{l}51^{\circ} 29^{\prime} 08^{\prime \prime} \mathrm{N} \\
22^{\circ} 56^{\prime} 34^{\prime \prime} \mathrm{E}\end{array}$ & 24.8 & 596 & 416 & 10.3 & 3.7 & 915 & $2^{\circ} 20^{\prime}$ \\
\hline Głębokie & $\begin{array}{l}51^{\circ} 28^{\prime} 34^{\prime \prime} \mathrm{N} \\
22^{\circ} 55^{\prime} 23^{\prime \prime} \mathrm{E}\end{array}$ & 20.5 & 585 & 350 & 7.1 & 3.4 & 689 & $2^{\circ} 10^{\prime}$ \\
\hline Gumienek & $\begin{array}{l}51^{\circ} 30^{\prime} 14^{\prime \prime} \mathrm{N} \\
22^{\circ} 56^{\prime} 20^{\prime \prime} \mathrm{E}\end{array}$ & 8.1 & 376 & 215 & 7.8 & 3.8 & 307 & $3^{\circ} 50^{\prime}$ \\
\hline Maśluchowskie & $\begin{array}{l}51^{\circ} 28^{\prime} 03^{\prime \prime} \mathrm{N} \\
22^{\circ} 56^{\prime} 43^{\prime \prime} \mathrm{E}\end{array}$ & 26.7 & 861 & 310 & 9.4 & 4.6 & 1231 & $3^{\circ} 00^{\prime}$ \\
\hline
\end{tabular}


expressed by the lake area to lake volume ratio (Tab. 1), which ranged from 0.22 in Lake Maśluchowskie to 0.29 in Lake Głębokie. The water bodies are situated in the agricultural landscape. The catchment basins of the lakes Głębokie, Gumienek and Maśluchowskie consist of arable lands $(20.5-73.5 \%)$, forests $(0.57-23.9 \%)$ and meadows (4.67-7.57\%). Lake Czarne has been surrounded by an earth dyke since the 1950s and has a largely limited area of the catchment basin (Ejankowski and Lenard, 2014).

Climatic data on air temperature and precipitation for a meteorological station in the town of Włodawa located in the Polesie region were taken from the online service (www.tutiempo.net). Mean air temperature for the periods of 14 days before sampling $\left(\mathrm{T}_{14}\right)$ and total precipitation of one hydrologic year before sampling, which strongly affects the water level of lakes in the Polesie region (Michalczyk et al., 2010), were included in the analyses.

We assumed mid-March as an average time for winter ice cover breakup in Poland (Marszelewski and Skowron, 2006). The effects of the cold winter (CW) were studied in the years when the latest ice break-up date $\left(\mathrm{L}_{\mathrm{bd}}\right)$ was observed later than mid-March, whereas the effects of the mild winter (MW) were studied when $\mathrm{L}_{\mathrm{bd}}$ occurred before this period. Prior to calculations, ranks were assigned to average dates of ice-out in 2010-2014: 1=11-20 February; 2=1-10 March; 3=21-31 March; 4=1-10 April; 5=21-30 April. According to the differences between the two periods (CW and MW), the physicochemical parameters, the biomass of macrophytes and the amount of phytoplankton expressed by the concentration of chlorophyll- $a$ were analysed.

Water sampling was conducted fortnightly, from May to the end of July (six samples per year in each lake, 120 samples in total). Mixed water samples were collected from depths of $0.5,1.5$ and $3 \mathrm{~m}$ from the sublittoral zone of the lakes with a Ruttner water sampler (2.0 L capacity). Then, they were analysed in a laboratory with the use of spectrophotometric methods to determine the concentration of chlorophyll- $a$ (Nush, 1980), total phosphorus (TP), total nitrogen $(\mathrm{TN})$, inorganic phosphorus $\left(\mathrm{P}^{-} \mathrm{PO}_{4}\right)$ and nitrogen (DIN=N-NO $\left.{ }_{\mathrm{x}}+\mathrm{N}-\mathrm{NH}_{4}\right)$ according to the procedures of Hermanowicz et al. (1999). The physicochemical parameters i.e., electrolytic conductivity (EC), water reaction $(\mathrm{pH})$ and transparency by Secchi disk visibility (SD) were measured in situ. Additionally, photosynthetic active radiation (PAR, $I_{z}$ ) was measured by a Li-Cor $192 \mathrm{SA}$ underwater quantum flat meter. Then, the vertical light attenuation coefficient $\left(\mathrm{K}_{\mathrm{d}}\right)$ between adjacent depth intervals $(z$ and $z+0.5 \mathrm{~m})$ was calculated as:

$\mathrm{K}_{\mathrm{d}}=\left(\ln \left(I_{z}\right)-\ln \left(I_{z+0.5 \mathrm{~m}}\right)\right) 0.5 \mathrm{~m}^{-1}$

where $I_{z}$ is the PAR value of a depth z (Kirk, 1994).

The study of the submerged aquatic vegetation (SAV) in the lakes focused on changes in the biomass of macrophytes after the $\mathrm{CW}$ and the MW. The research was conducted at permanent study sites situated randomly in the phytolittoral zone of the lakes. The water depth of the macrophyte sampling depended on the extension of the vegetation in particular lakes. The study sites were marked in 2010 and located using a GPS receiver (Garmin 60Cx) in the consecutive years. Every year in August, 35-40 replicates were performed randomly in the phytolittoral of each lake with a rake sampler from $0.4 \times 0.4 \mathrm{~m}$ quadrats. During 2010-2014, 765 samples of the SAV biomass were collected. Additionally, a water depth from the surface to the ground occupied by the sampled macrophytes was measured each time. Plants were cleaned, dried at a temperature of $105^{\circ} \mathrm{C}$ to constant weight and weighed.

The data were $\log$-transformed $\left(\log _{10} \mathrm{x}+1\right)$ prior to analysis or non-parametric tests were used if data did not meet the assumptions of parametric tests. The normality of data was tested by the Lilleforst test and the homogeneity of variance was analysed by the Levene's test. Two qualitative categories - the CW and MW or rank system $\mathrm{L}_{\mathrm{bd}}$ were used depending on the type of statistical method. Fisher's test (F-test) in ANCOVA was employed to analysed the influence of factors: the type of winter (the $\mathrm{CW}$ and $\mathrm{MW}$ ), the kind of lake and covariates: total precipitation of one hydrologic year and water depth of sampled macrophytes on the physicochemical and biological parameters. In the statistical models the total precipitation was insignificant and excluded from the following analyses. Thus, in the case of the physicochemical parameters and the concentration of chlorophyll- $a$, ANOVA was used to determine the effects of the $\mathrm{CW}$ and $\mathrm{MW}$ and kind of lake. Relationships between the parameters describing the water transparency ( $\mathrm{SD}$ and $\mathrm{K}_{\mathrm{d}}$ ), phytoplankton (the concentration of chlorophyll- $a$ ) and nutrients (DIN, TN) were evaluated by non-parametric Spearman's correlation test, in which the rank system of $\mathrm{L}_{\mathrm{bd}}$ was used. All calculations were performed according to Sokal and Rohlf (1995) using Statistica 10.

\section{RESULTS}

In the studied lakes in 2010-2014, the $\mathrm{L}_{\mathrm{bd}}$ occurred in different periods of the year, and varied from the middle of February (winter period) to the end of April (spring period). After the CW, the $\mathrm{L}_{b d}$ was observed between 21 and 31 March (2012) or 1 and 10 and 21 and 30 April 2010 and 2013, respectively. After the MW in 2011 and 2014, early ice-out was observed due to relatively high mean air temperatures (www.tutiempo.net). The $\mathrm{L}_{\mathrm{bd}}$ in 2011 occurred between 11 and 20 February and in 2014 between 1 and 10 March. During studies, total precipitation in one hydrologic year varied in a broad range, from $481.5 \mathrm{~mm}$ in 2013 to 717.6 in 2012. However, they were comparable in periods after the CW $(636.2 \mathrm{~mm})$ and the MW $(629.1 \mathrm{~mm})$. 
During the course of the study, the concentration of total nitrogen (TN) and phosphorus (TP) changed simultaneously in all lakes. The alteration of both parameters corresponded with the extreme winters. The highest concentration and variation of TP values were measured in 2013 (the CW) and were very low in 2010-2012 and 2014. Only in a single case, Lake Głębokie, was the increase of TP concentration in 2013 less noticeable (Fig. 1a). On the other hand, the concentration of TN was the highest in 2011 (the MW) and much lower in the remaining years (Fig. 1b).

Other parameters differed considerably in particular lakes. Changes in the values of $\mathrm{K}_{\mathrm{d}}$ in 2010-2014 presented a similar pattern as TN, with the maximum in 2011 and very high values in 2014 , contrary to low $\mathrm{K}_{\mathrm{d}}$ in 2010, 2012 and 2013 (Fig. 1d). The $\mathrm{K}_{\mathrm{d}}$ values were negatively correlated with the SD visibility (Spearman's $\mathrm{R}=-0.84$, $\mathrm{P}<0.001)$ and positively correlated with the concentration of chlorophyll- $a$ in water (Spearman's $\mathrm{R}=0.88, \mathrm{P}<0.001$ ). The lowest $\mathrm{K}_{\mathrm{d}}$ and concentration of chlorophyll- $a$ and the highest SD values were recorded in Lake Czarne, whereas the highest $\mathrm{K}_{\mathrm{d}}$ and chlorophyll- $a$ and the lowest SD were observed in Lake Głębokie (Fig. 1 c,e).

The chlorophyll- $a$ concentration increased with the mean air temperature $\left(\mathrm{T}_{14 \text { days }}\right.$, Spearman's $\left.\mathrm{R}=0.25, \mathrm{P}<0.01\right)$ and slightly decreased with the ranged date of the latest ice break-up - $\mathrm{L}_{\mathrm{bd}}$ (Fig. 2). The large dispersion of the chlorophyll- $a$ in relation to $\mathrm{L}_{\mathrm{bd}}$ in the scatter plot was caused by considerable differences between particular lakes (Fig. 2).
However, the mean values of chlorophyll- $a$ were generally higher after the MW than the CW (Tab. 2).

In the studied lakes, many parameters corresponded to the type of winter. In spite of their high differences in particular lakes, expressed by standard deviations, the effects of CW and MW were revealed. In accordance with the concentration of chlorophyll- $a$, the $\mathrm{K}_{\mathrm{d}}$ was higher and the SD was lower after the MW than after the CW (Tab. 2). The phytoplankton biomass was correlated with the elevated concentration of soluble (Spearman's $\mathrm{R}=0.21, \mathrm{p}<0.05$ ) and total nitrogen (Spearman's $\mathrm{R}=0.43, \mathrm{P}<0.001$ ). The water chemistry showed some differences between the two observed periods. After the MW, the values of TN, DIN and the ratio DIN/TN and TN/TP were higher, and the value of TP was lower than after the CW. Nonetheless, no differences in the electrolytic conductivity, $\mathrm{P}_{-} \mathrm{PO}_{4}$ and $\mathrm{pH}$ were found between the compared periods (Tab. 2).

In the studied lakes, the SAV was composed mainly of three abundant species: Ceratophyllum demersum L., Myriophyllum spicatum L. and Stratiotes aloides L. (Fig. 3). The hornwort ( $C$. demersum) was the most common macrophyte species in the lakes Głębokie, Czarne and Gumienek, whereas the water milfoil M. spicatum dominated over C. demersum in Lake Maśluchowskie. The water soldier ( $S$. aloides) was abundant only in Lake Czarne (Fig. 3). Other species, such as Potamogeton lucens L., P. acutifolius Link, P. natans L., Nuphar lutea (L.) Sibth. \& Sm. and Elodea canadensis Michx., were found only occasionally in the lakes.

Tab. 2. Mean values ( \pm standard deviations) of submerged aquatic vegetation and particular macrophyte biomass, chlorophyll- $a$ concentration (Chl- $a$ ) and physicochemical parameters in eutrophic lakes compared between the growing seasons after the cold and the mild winter in the best fitted models of ANCOVA or ANOVA. Selected effects related to the types of winter are presented below.

\begin{tabular}{|c|c|c|c|c|}
\hline Parameter & $\mathrm{CW}$ & MW & df & F-test \\
\hline Total SAV $\left(\mathrm{g} \mathrm{m}^{-2}\right)^{\circ}$ & $112.7( \pm 119.3)$ & $77.9( \pm 100.1)$ & 1 & $25.09 * * *$ \\
\hline Ceratophyllum demersum $\left(\mathrm{g} \mathrm{m}^{-2}\right)^{\circ}$ & $86.8( \pm 120.5)$ & $70.4( \pm 98.9)$ & 1 & $4.07 *$ \\
\hline Myriophyllum spicatum $\left(\mathrm{g} \mathrm{m}^{-2}\right)^{\circ}$ & $34( \pm 54.3)$ & $11( \pm 16.4)$ & 1 & $21.2 * * *$ \\
\hline Stratiotes aloides $\left(\mathrm{g} \mathrm{m}^{-2}\right)^{\circ}$ & $32.8( \pm 44.6)$ & $15.6( \pm 28.4)$ & 1 & $7.62 * *$ \\
\hline Chl-a $\left(\mu \mathrm{g} \mathrm{L}^{-1}\right)^{\#}$ & $18.9( \pm 14.6)$ & $20( \pm 19.4)$ & 1 & $5.62 *$ \\
\hline $\mathrm{Kd}\left(\mathrm{m}^{-1}\right)^{\#}$ & $1.2( \pm 0.5)$ & $1.5( \pm 0.7)$ & 1 & $9.49 * *$ \\
\hline $\mathrm{SD}(\mathrm{m})^{\#}$ & $2.12( \pm 1.1)$ & $1.98( \pm 1.1)$ & 1 & $4.4^{*}$ \\
\hline Water temperature $\left({ }^{\circ} \mathrm{C}\right)^{\#}$ & $21.7( \pm 3.1)$ & $21.1( \pm 2.7)$ & 1 & 1.26 \\
\hline $\left.\mathrm{EC}(\mu \mathrm{S} \mathrm{cm})^{-1}\right)^{\#}$ & $228( \pm 76.7)$ & $232.7( \pm 83.5)$ & 1 & 0.67 \\
\hline $\mathrm{pH}^{\#}$ & $7.96( \pm 0.3)$ & $7.97( \pm 0.3)$ & 1 & 0.03 \\
\hline $\mathrm{TN}\left(\mathrm{mg} \mathrm{L}^{-1}\right)^{\#}$ & $1.9( \pm 0.8)$ & $3.7( \pm 1.6)$ & 1 & $78.5 * * *$ \\
\hline $\mathrm{TP}\left(\mathrm{mg} \mathrm{L}^{-1}\right)^{\#}$ & $0.18( \pm 0.2)$ & $0.04( \pm 0.02)$ & 1 & $14.53 * * *$ \\
\hline P-PO4 (mg L-1) \# & $0.03( \pm 0.03)$ & $0.01( \pm 0.05)$ & 1 & $14.98 * * *$ \\
\hline $\operatorname{DIN}\left(\mathrm{mg} \mathrm{L}^{-1}\right)^{\#}$ & $0.52( \pm 0.4)$ & $2.08( \pm 1.2)$ & 1 & $104.56^{* * *}$ \\
\hline DIN:TN"\# & $0.3( \pm 0.3)$ & $0.5( \pm 0.2)$ & 1 & $26.61 * * *$ \\
\hline P-PO4:TP\# & $0.3( \pm 0.5)$ & $0.3( \pm 2.3)$ & 1 & 0.84 \\
\hline $\mathrm{TN}: \mathrm{TP}^{\#}$ & $31( \pm 24.7)$ & $102( \pm 61.3)$ & 1 & $75.01 * * *$ \\
\hline
\end{tabular}

$C W$, cold winter; $M W$, mild winter; df, degree of freedom; SAV, submerged aquatic vegetation; Kd, attenuation coefficient; SD, Secchi disk visibility; EC, electrolytic conductivity; TN, total nitrogen; TP, total phosphorus; DIN, dissolved inorganic nitrogen. ${ }^{\circ}$ ANCOVA; ${ }^{\sharp} A N O V A . * P<0.05 ; * * P<0.01 ; * * * P<0.001$. 
The average water depth of the macrophyte colonisation was $1.83 \mathrm{~m}$ in Lake Głębokie, $2.03 \mathrm{~m}$ in Lake Gumienek, $2.72 \mathrm{~m}$ in Lake Maśluchowskie and $3.04 \mathrm{~m}$ in Lake Czarne. In accordance with our assumptions, the biomass of macrophytes (SAV) decreased with water depth of sampling (ANCOVA, F=76.96, $\mathrm{P}<0.001$ ) and increased with water transparency, $\mathrm{SD}(\mathrm{F}=293.07$, $\mathrm{P}<0.001)$. The negative effect of light limitation on the biomass macrophytes was noticeable in lakes Głębokie, Maśluchowskie and Gumienek. Only in Lake Czarne was
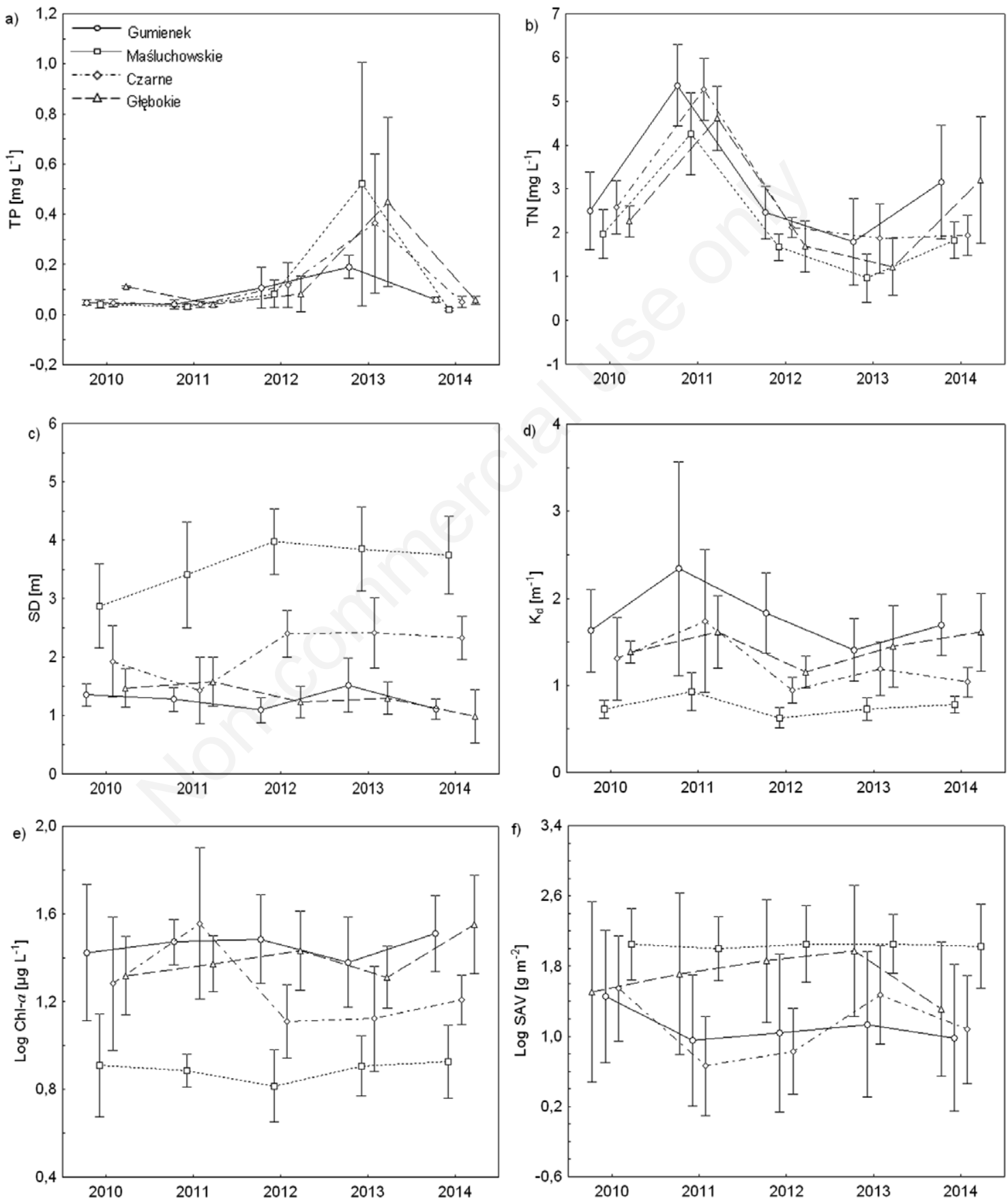

Fig. 1. Mean values ( \pm standard deviations) of physicochemical and biological parameters of water in the studied lakes in $2010-2014$. The concentration of chlorophyll- $a(\mathrm{Chl}-a)$ and the biomass of submerged aquatic vegetation (SAV) were $\log$-transformed (log $10 \mathrm{x}+1)$. $\mathrm{TP}$, total phosphorus; TN, total nitrogen; SD, Secchi disk visibility; $\mathrm{K}_{\mathrm{d}}$, attenuation coefficient. 
the biomass of macrophytes constantly very high (Fig. 1f), in spite of considerable changes in the average seasonal (May-July) water transparency (SD) from 2.87 (2010) to $3.98 \mathrm{~m}$ (2012), the $\mathrm{K}_{\mathrm{d}}$ from 0.69 (2012) to 0.95 (2011) and the concentration of chlorophyll- $a$ from 5.95 (2012) to $8.37 \mu \mathrm{g} \mathrm{L}^{-1}$ (2014).

The abundance of the SAV in the periods following the $\mathrm{CW}$ and the MW corresponded with differences in the physicochemical and biological parameters. The total biomass of the SAV was much higher after the $\mathrm{CW}$ than after the MW (Tab. 2). This was reflected in the relatively high total biomass of the macrophytes in 2010 and 2013 (CW) and decreasing SAV in 2011 and 2014 (MW, Fig. 1f). The effect of winter (early or late ice-out) was important to all macrophyte species, but it was highly significant and much stronger in Myriophyllum spicatum and Stratiotes aloides than in Ceratophyllum demersum (Tab. 2, Fig. 3).

\section{DISCUSSION}

The projected climate warming will have a profound effect on the shortening of the duration and thickness of the ice cover (McCarthy et al., 2001; Leppäranta, 2010; Livingstone et al., 2010). The earlier ice-out on lakes determines changes in the physicochemical parameters, which are important to the abundant development of phytoplankton in spring (Weyhenmeyer et al., 2008; Laugaste et al., 2010; Nõges et al., 2010). However, our results show that the effect of mild winters on lakes can also be observed in following growing season (Tab. 2).

In the studied lakes, the concentration of nutrients varied in the broad range and was determined by the winter periods. After the $\mathrm{CW}$, a high concentration of total and soluble phosphorus in water was observed, whereas total and soluble nitrogen increased after the MW. Although the effects of CW and MW on nutrients were significant (Tab. 2), they were highly noticeable only after extreme warm (2011) and cold (2013) winters (Fig. 1 $\mathrm{a}, \mathrm{b})$. The values of TP and TN varied over time, whereas their changes among lakes were simultaneous (Fig. 1 $a, b)$, which suggested the occurrence of a general external effect, most likely dependent on climatic conditions. Synchronous variations, however, in dissolved organic carbon and water colour affected by precipitation and data of ice-out were reported by Pace and Cole (2002). Nutrients concentration in water can also be influenced by precipitation, which could be a source of inorganic nitrogen from the atmosphere and enhanced surface runoff from the catchment basin, especially dominated by arable lands (Smal et al., 2005; Hessen et al., 2009). Our results showed that total precipitation linked with the $\mathrm{CW}$ and the MW was comparable and, in turn, should have a negligible effect on the highest or the lowest TP and TN concentrations. The alternative source of nitrogen in water could be the biological fixation of atmospheric $\mathrm{N}_{2}$ by cyanobacteria (Howarth et al., 1988; Cottingham et al., 2015), however, these blue-green algae have never dominated in the studied lakes (Wojciechowska and Solis, 2009; unpublished data).

It seems that a stronger impact on low TP concentration could have short periods of ice cover, which affected the reduction of winter anoxia and the successive decrease of phosphate release from the sediments, as reported by other authors (Stefan and Fang, 1993; McCarthy et al., 2001). In contrary, due to a long duration of ice cover, the increase of TP concentration in the studied lakes was recorded after the $\mathrm{CW}$. On the other hand, based on the observations of Klimaszyk and Rzymski (2011), higher phosphorus concentration after the CW could be linked with increased surface runoff after snow and ice melting. Relatively high phosphorus concentration in the studied lakes after the CW could be associated with the agricultural land use in the catchment basin.
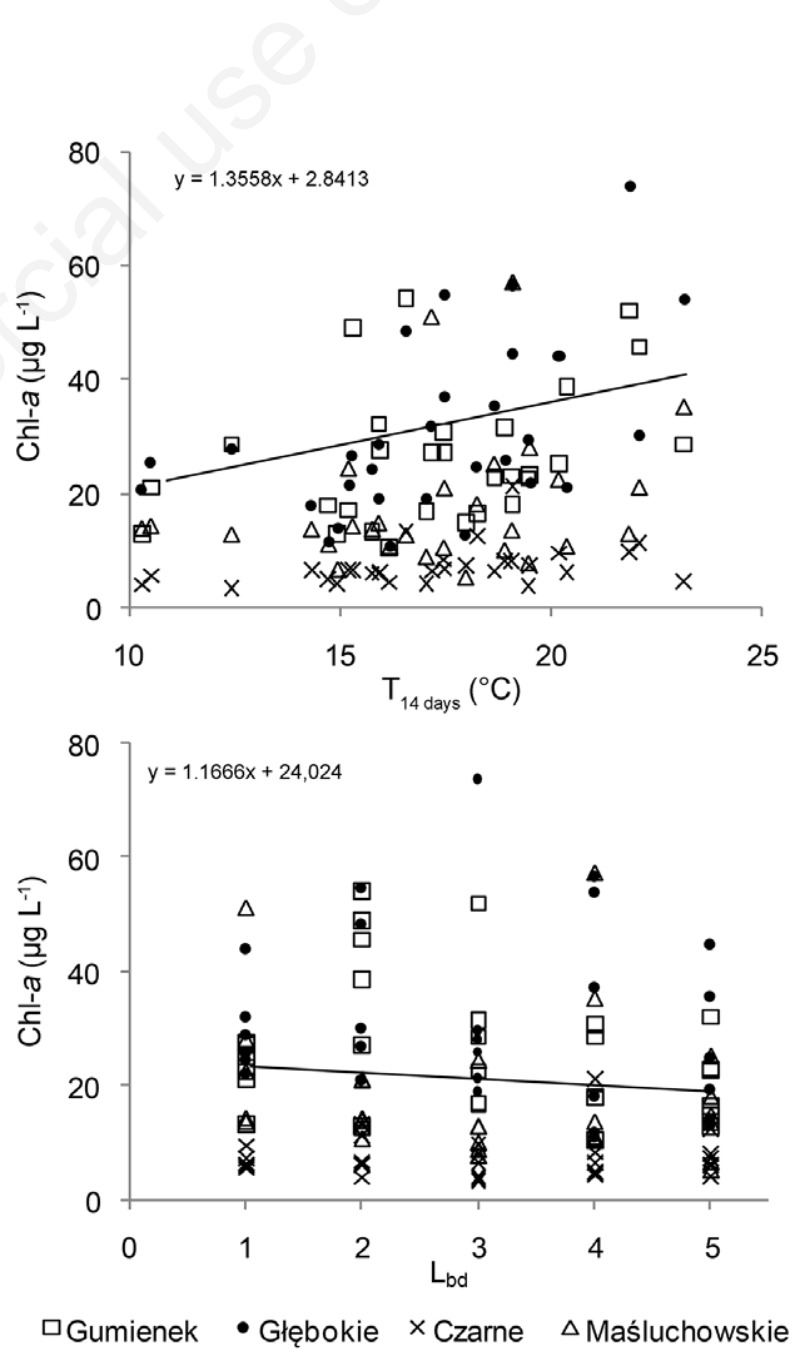

Fig. 2. Relationships between the concentration of chlorophyll$a(\mathrm{Chl}-a)$ and the mean air temperature $\left(\mathrm{T}_{14 \text { days }}\right)$, and ranges of the latest ice break-up date $\left(\mathrm{L}_{\mathrm{bd}}\right)$ in the studied lakes. 
We speculate that higher nitrogen concentration after the MW can be a result of a long period of wind-induced water mixing. The depth of effective water mixing in the lakes, calculated according to Patalas formula (1984) modified by Padisák and Reynolds (2003), varied from $2.7 \mathrm{~m}$ in Lake Gumienek to $4 \mathrm{~m}$ in Lake Maśluchowskie and was often close to the mean water depths in lakes (Tab. 1). Intensified sediment resuspension accompanied by ice-free conditions in winter plays a major role as an internal supply of nitrogen in water, e.g., ${\mathrm{N}-\mathrm{NH}_{4}, \mathrm{TN}}$ (Reddy et al., 1996; Nõges et al., 1998). Thus, in the studied lakes, the TN:TP ratio was considerably higher after the MW compared with the CW. This is consistent with other studies in shallow and deep lakes of Central and Northern Europe (Salmaso, 2002; Laugaste et al., 2010) and inconsistent with the results from the different lakes of Western Europe, in which heavy winter rains tend to transport large portion of dissolved phosphorus into water (George et al., 2004). Differences in other physicochemical parameters of water (EC, $\mathrm{pH}$ and temperature) were statistically insignificant in growing seasons after the compared winter types (the $\mathrm{CW}$ and the MW).

The phytoplankton biomass is usually linked with increased nutrient concentration and temperature (Schindler et al., 1990; Moss et al., 2003). The thermal conditions influenced phytoplankton biomass in the studied lakes (Fig. 2); however, there was no difference in the mean water temperature after the $\mathrm{CW}$ and the MW (Tab. 2). According to our results, the more important factor determining high phytoplankton biomass, associated with ice cover duration on lakes, was the increased nutrient concentration. Consequently, light limitations induced by phytoplankton growth caused deterioration of submerged vegetation after mild winters. In contrast, high nutrient concentration and low phytoplankton biomass after mild winter was reported by Pełechata et al. (2015) in a small Chara-lake, in which the charophyte vegetation developed and strongly counteracted the excessive growth of phytoplankton. In the studied lakes in the Polesie region, which are phytoplankton- or macrophyte-dominated, non-

a)

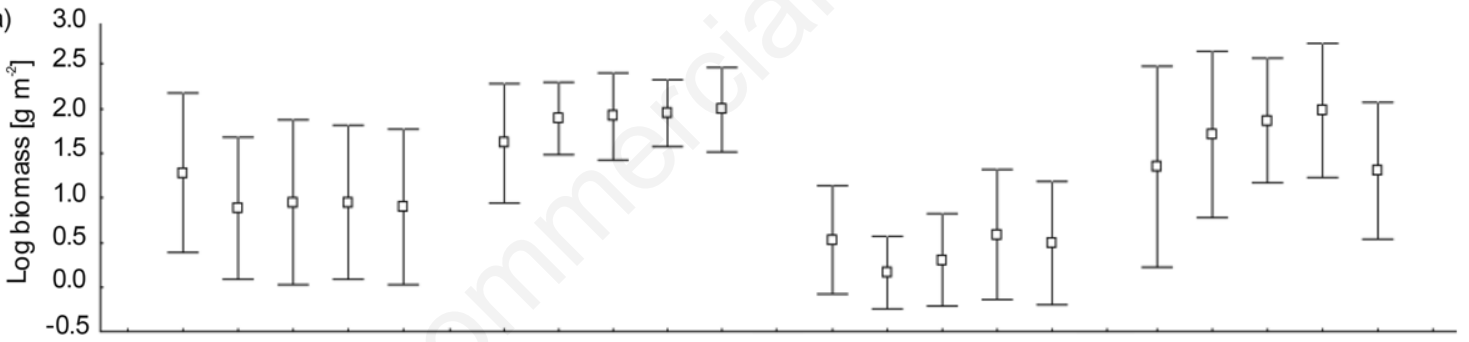

b)
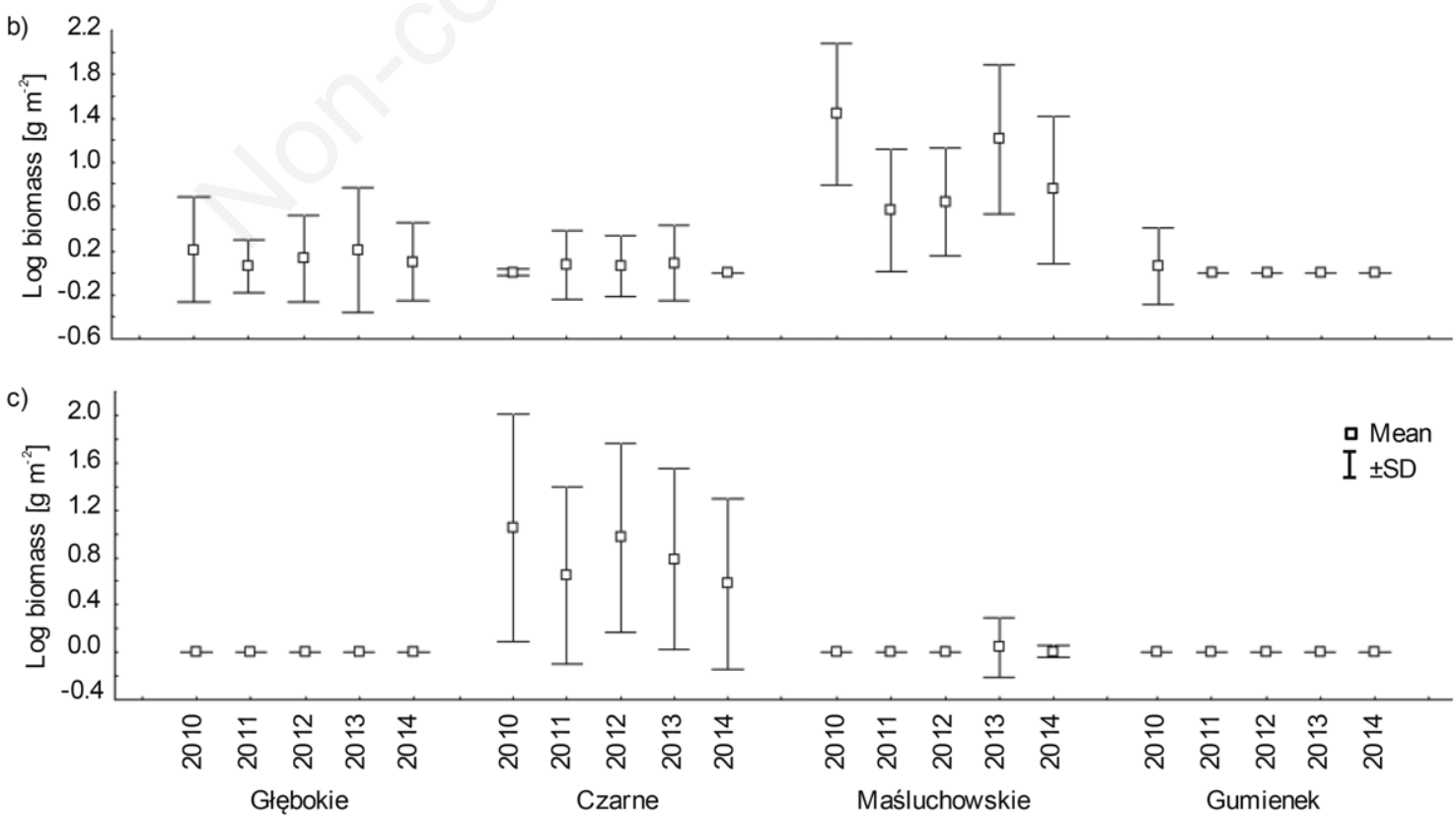

Fig. 3. Temporal variation in the log-transformed biomass $\left(\log _{10} \mathrm{x}+1\right)$ with standard deviations $( \pm$ SD) of submerged macrophytes: a) Ceratophyllum demersum; b) Myriophyllum spicatum; and c) Stratiotes aloides in the studied lakes in 2010-2014. 
overwintering species (C. demersum, $M$. spicatum) comprise benthic vegetation. Macrophytes such as milfoil and hornwort can influence the development of phytoplankton to a lesser extent than overwintering charophytes (van Donk and Van de Bund, 2002), which additionally reduce water turbidity (Casanova et al., 2002).

Zooplankton grazing can reduce the abundance of phytoplankton in waters (Gyllström et al., 2005; Jeppesen et al., 2010). High water temperature in late spring has a strong impact on the emergence and development of zooplankton populations and can lead to an early clear water phase in lakes (Straile, 2000; Gerten and Adrian, 2000; Asaeda et al., 2001). In the studied lakes, however, there were no differences in the mean water temperature between periods after the CW and the MW (Tab. 2), which suggests that the differences in zooplankton and phytoplankton development after both periods could be independent on thermal conditions. The temperature of water, however, affected the phytoplankton biomass during the growing season (Fig. 2). The grazing pressure on phytoplankton in shallow eutrophic waters, such as the studied lakes, is often negligible compared with deep mesotrophic ones (Jeppesen et al., 1997). Moreover, the studied lakes are dominated by filamentous blue-green algae (Wojciechowska and Solis, 2009) that may affect the filtration capacity of zooplankton by interference and make them less edible (de Bernardi and Giussani, 1990). Thus, the variation in the concentration of chlorophyll- $a$ between both winter periods was most likely independent on the grazing of zooplankton.

High concentrations of nutrients and chlorophyll- $a$ in water resulted in changes in water transparency expressed by SD visibility and the values of $\mathrm{K}_{\mathrm{d}}$, which is consistent with the results of other studies (Tilzer et al., 1995; Asaeda et al., 2001). Poor underwater light climate in the studied lakes after the MW was stressful for the SAV, except for Lake Czarne, in which the biomass of SAV was continuously very high during the studies (Fig. 1f). In this lake, the highest values of water transparency and the lowest values of $\mathrm{K}_{\mathrm{d}}$ were noted (Fig. $1 \mathrm{c}$, d). In Lake Czarne, a large part of the lake bottom (65\%) is covered by macrophytes and submerged vegetation reached a depth $(4.5 \mathrm{~m})$ higher than the depth of effective water mixing $(3.4 \mathrm{~m})$. Additionally, the lake is surrounded by large belt of emerged vegetation that reduces wave action in the water body and indirectly limits sediment resuspension and improves water transparency. An inverse effect was found in other lakes, such as Głębokie, in which the maximum depth of macrophyte colonisation $(2.5 \mathrm{~m})$ was lower than the depth of effective water mixing $(3.4 \mathrm{~m})$. In this lake, a large part of the bottom (ca. 60\%) was devoid of vegetation and exposed to turbulence (Ejankowski and Lenard, 2014). In Lake Czarne, macrophyte dominance could hamper the development of phytoplankton by different mechanisms, i.e. competition on nutrients end allelopathic effects (Scheffer et al., 1993; Nakai et al., 1999; Pełechata et al., 2015). According to other studies (Ali et al., 1995, 2011; Ejankowski and Solis, 2015), we speculate that the light climate in this lake was still favourable for the SAV and much above the species tolerance level, independently on the type of winter.

Light conditions in lakes can be influenced by suspended particles and dissolved organic compounds, which affect water colour (Wetzel, 2001; Pace and Cole, 2002). Our findings are consisted with the observations of Blindow (1992) that the light climate for the development of SAV may be determined by water turbidity linked with particulate matter including phytoplankton. Interestingly, in the studied lakes, the effect of SD on the SAV was determined to be less important than $\mathrm{K}_{\mathrm{d}}$ and the concentration of chlorophyll- $a$. This is because in highly eutrophic lakes with high water turbidity, SD values reflect the quality of the upper water layer only, whereas $\mathrm{K}_{\mathrm{d}}$ and the concentration of chlorophyll- $a$ were measured within the whole water column and reflected the light conditions from the water surface to the depth occupied by macrophytes. Considerable differences in the concentration of chlorophyll- $a$ and the $\mathrm{K}_{\mathrm{d}}$ through the water column were observed, in stratified lakes with a deep chlorophyll maximum (Micheletti et al., 1998; Walsby et al., 2001). Therefore, we suggest that $K_{d}$ and the concentration of chlorophyll- $a$ provide more precise data on the light climate for the SAV and more strictly results in the analysis of the relationships between light intensity and the development of macrophytes.

The conditions in the cold winter, in terms of a long period of ice cover combined with an increase in the ice thickness, are unfavourable to emergent aquatic macrophytes (Alahuhta et al., 2011). On the contrary, submerged macrophytes were reported to be positively correlated with the duration of ice cover on a lake, as an effect of winter fish kill (Hargeby et al., 2004). Long periods of ice cover may lead to winter fish kill that reduce predation pressure on zooplankton and consequently strengthen zooplankton grazing on phytoplankton (Gyllström et al., 2005; Jeppesen et al., 2010). Low phytoplankton biomass affects favourable light conditions in water and encourages the development of submerged macrophytes in a lake. During the five years of the study, the effect of anoxia under the ice cover has never been observed, which could be linked with a relatively high mean water depth $(>3.4 \mathrm{~m})$ in the lakes. Therefore, the impact of winter fish kill can be omitted in the studied lakes.

Changes in the environmental conditions in lakes, such as the concentration of nutrients, the light climate and the water level, can result in the abundance and composition of SAV (Wallsten and Forsgren, 1989; Blindow, 1992; Ejankowski and Solis, 2015). Responses to light 
conditions of SAV may vary in particular macrophyte species (Nurminen, 2003). In the studied lakes, the light deficiency related to an increase in water turbidity after the MW had a strong negative effect on the macrophytes, which are moderately light-demanding species (Zarzycki et al., 2002). The stronger effect on Myriophyllum spicatum L. and Stratiotes aloides L. than on Ceratophyllum demersum L. can be explained by their lower tolerance to water turbidity (Haslam, 1997; Szoszkiewicz et al., 2010). The shade tolerance of $C$. demersum seems to be the main factor responsible for the relatively high abundance and common occurrence of this species in many turbid water bodies (Ali et al., 1995, 2011). Deteriorated water quality had a relatively small effect on the abundance of the hornwort that can potentially determine its strong competition ability in the lake ecosystems.

\section{CONCLUSIONS}

Our findings show that the term of ice cover melting, acting through the concentration of nutrients, the phytoplankton biomass and water turbidity, affects the biomass of the SAV in the lakes. Thus, cold and mild winters can change the balance between the phytoplankton and benthic vegetation in shallow eutrophic lakes, as a shift between the clear and turbid water states in terms of the alternative state theory proposed by Scheffer et al. (1993). We speculate that various responses of particular macrophytes to changes in the water quality after the cold or mild winters could be a cause of the alterations in the vegetation structure, particularly, the expansion of shade-tolerant species instead of light-demanding ones after a series of mild winters.

\section{REFERENCES}

Alahuhta J, Vuori K-M, Luoto M, 2011. Land use, geomorphology and climate as environmental determinants of emergent aquatic macrophytes in boreal catchments. Boreal Env. Res. 16:185-202.

Ali MM, Hamad AM, Springuel IV, Murphy KJ, 1995. Environmental factors affecting submerged macrophyte communities in regulated water bodies in Egypt. Arch. Hydrobiol. 133:107-128.

Ali MM, Hassan SA, Shaheen AM, 2011. Impact of riparian trees shade on aquatic plant abundance in conservation islands. Acta Bot. Croat. 70:245-258.

Asaeda T, Bon TV, 1997. Modeling the effects of macrophytes on algal blooming in eutrophic shallow lakes. Ecol. Model. 104:261-287.

Asaeda T, Trung VK, Manatunge J, Van Bon T, 2001. Modelling macrophyte-nutrient-phytoplankton interactions in shallow eutrophic lakes and the evaluation of environmental impacts. Ecol. Eng. 16:341-357.

Barko JW, Hardin DG, Matthews MS, 1982. Growth and morphology of submersed macrophytes in relation to light and temperature. Can. J. Bot. 60:877-887.
Blindow I, 1992. Long- and short-term dynamics of submerged macrophytes in two shallow eutrophic lakes. Freshwater Biol. 28:15-27.

Casanova MT, de Winton MD, Clayton JS, 2002. Do charophytes clear turbid waters? Verh. Internat. Verein. Limnol. 28:1440-1443.

Christoffersen KS, Amsinck SL, Landkildehus F, Lauridsen TL, Jeppesen E, 2008. Lake Flora and Fauna in Relation to IceMelt, Water Temperature and Chemistry at Zackenberg, p. 371-390. In: H. Meltofte, T.R. Christensen, B. Elberling, M.C. Forchhammer and M. Rasch (eds.), High-arctic ecosystem dynamics in a changing climate. Elsevier, Amsterdam.

de Bernardi R, Giussani G, 1990. Are blue-green algae suitable food for zooplankton? An overview. Hydrobiologia 200/201: $29-41$.

Degirmendžić J, Kożuchowski K, Żmudzka E, 2004. Changes of air temperature and precipitation in Poland in the period 1951-2000 and their relationship in to atmospheric circulation. Int. J. Climatol. 24:291-310.

Dokulil MT, 2014. Predicting summer surface water temperatures for large Austrian lakes in 2050 under climate change scenarios. Hydrobiologia 731:19-29.

Ejankowski W, Lenard T, 2014. Trophic state of a shallow lake with reduced inflow of surface water. Arch. Environ. Prot. 40:3-11.

Ejankowski W, Lenard T, 2015. Climate driven changes in the submerged macrophyte and phytoplankton community in a hard water lake. Limnologica 52:59-66.

Ejankowski W, Solis M, 2015. Response of hornwort (Ceratophyllum demersum L.) to water level drawdown in a turbid water reservoir. Appl. Ecol. Environ. Res. 13:219-228.

George DG, Maberly SC, Hewitt DP, 2004. The influence of the North Atlantic Oscillation on the physical, chemical and biological characteristics of four lakes in the English Lake District. Freshwater Biol. 49:760-774.

Gerten D, Adrian R, 2000. Climate-driven changes of spring phytoplankton dynamics and the sensitivity of shallow polymictic lakes to the North Atlantic Oscillation. Limnol. Oceanogr. 45:1058-1066.

Gerten D, Adrian R, 2001. Differences in the persistency of the North Atlantic Oscillation signal among lakes. Limnol. Oceanogr. 46:448-455.

Gyllström M, Hansson L-A, Jeppesen E, Garcia-Criado F, Gross E, Irvine K, Kariesalo T, Kornijów R, Miracle MR, Nykänen M, Nõges T, Romo S, Stephen D, Van Donk E, Moss B, 2005. The role of climate in shaping zooplankton communities of shallow lakes. Limnol. Oceanogr. 50:2008-2021.

Haslam SM, 1997. The river scene: ecology and cultural heritage. Cambridge University Press, Cambridge: 344 pp.

Hargeby A, Blindow I, Hansson L-A, 2004. Shifts between clear and turbid states in a shallow lake: multi-causal stress from climate, nutrients and biotic interactions. Arch. Hydrobiol. 161:433-454.

Hermanowicz W, Dojlido J, Dożańska W, Koziorowski B, Zerbe J, 1999. [Fizyczno-chemiczne badanie wody i ścieków]. [Book in Polish] Wyd. Arkady, Warszawa: 556 pp.

Hessen DO, Andersen T, Larsen S, Skjelvåle BL, de Wit HA, 2009. Nitrogen deposition, catchment productivity, and climate as determinants of lake stoichometry. Limnol. Oceanogr. 54:2520-2528. 
Jeppesen E, Jensen JP, Søndergaard M, Lauridsen T, 1997. Topdown control in freshwater lakes: the role of nutrient state, submerged macrophytes and water depth, p. 151-164. In: L. Kufel, A. Prejs and J.I. Rybak (eds.), Shallow lakes '95. Kluwer, Dordrecht.

Jeppesen E, Lauridsen TL, Kairesalo T, Perrow MR, 1998. Impact of submerged macrophytes on fish-zooplankton interactions in lakes, p. 91-114. In: E. Jeppesen, M. Søndergaard, M. Søndergaard and K. Christoffersen (eds.), The structuring role of submerged macrophytes in lakes. Springer, New York.

Jeppesen E, Meerhoff M, Holmgren K, González-Bergonzoli I, Teixeira-de Mello F, Declerck SAJ, De Meester L, Søndergaard M, Lauridsen TL, Bjerring R, Conde-Porcuna JM, Mazzeo N, Iglesias C, Reizenstein M, Malmquist HJ, Liu Z, Balaya D, Lazzaro X, 2010. Impacts of climate warming on lake fish community structure and potential ecosystem effects. Hydrobiologia 646:73-90.

Kaszewski BM, Siwek K, Gluza AF, Siłuch M, 2009. Changes of the selected climatic components in the "West Polesie" Biosphere Reserve during 1951-2006 period, p. 138-152. In: T.J. Chmielewski, C. Słotwiński (eds.), Nature and Landscape monitoring system in the West Polesie region. Wyd. PZN, Warszawa.

Kirk JTO, 1994. Light and photosynthesis in aquatic ecosystems. Cambridge Univ. Press, Cambridge: 509 pp.

Klimaszyk P, Rzymski P, 2011. Surface runoff as a factor determining trophic state of midforest lake. Pol. J. Environ. Stud. 20:1203-1210.

Kondracki J, 2002. [Geografia regionalna Polski].[Book in Polish]. Wyd. Nauk. PWN, Warszawa: 440 pp.

Lenard T, Wojciechowska W, 2013. Phytoplankton diversity and biomass during winter with and without ice cover in the context of climate change. Pol. J. Ecol. 61:739-748.

Leppäranta M, 2010. Modelling the formation and decay of lake ice, p. 63-83. In: D.G. George (ed.), The impact of climate change on European lakes. Springer, Dordrecht.

Laugaste R, Haberman J, Blank K, 2010. Cool winters versus mild winters: effects on spring plankton in Lake Peipsi. Est. J. Ecol. 59:163-183.

Livingstone DM, Adrian R, Blenckner T, George G, Weyhenmeyer GA, 2010. Lake ice phenology, p. 51-61. In: D.G. George (ed.), The impact of climate change on European lakes. Springer, Dordrecht.

Madsen JD, Chambers PA, James WF, Koch EW, Westlake DF, 2001. The interaction between water movement, sediment dynamics and submersed macrophytes. Hydrobiologia 444:71-84.

Magnuson JJ, Robertson DM, Benson BJ, Wynne RH, Livingstone DM, Arai T, Assel RA, Barry RG, Card V, Kuusisto E, Granin NG, Prowse TD, Stewart KM, Vuglinski VS, 2000. Historical trends in lake and river ice cover in the northern hemisphere. Science 289:1743-1746.

Marszelewski W, Skowron R, 2006. Ice cover as an indicator of winter air temperature changes: Case study of the Polish Lowland lakes. Hydrolog. Sci. J. 51:336-349.

McCarthy JJ, Canziani OF, Leary NA, Dokken DJ, White KS, 2001. Climate change 2001: Impacts adaptation, and vulnerability. Contribution of WG II to the third assessment report of the IPCC. Cambridge University Press, Cambridge: 1032 pp.

Mckee D, Hatton K, Eaton JW, Atkinson D, Atherton A, Harvey
I, Moss B, 2002. Effects of simulated climate warming on macrophytes in freshwater microcosm communities. Aquat. Bot. 74:71-83.

Micheletti S, Schanz F, Walsby AE, 1998. The daily integral of photosynthesis by Planktothrix rubescens during summer stratification and autumnal mixing in Lake Zürich. New Phytol. 139:233-246.

Moss B, Mc Kee D, Atkinson D, Collings SE, Eaton JW, Gill AB, Harvey I, Hatton K, Heyes T, Wilson D, 2003. How important is climate? Effects of warming, nutrient addition and fish on phytoplankton in shallow lake microcosms. J. App. Ecol. 40:782-792.

Nakai S, Inoue I, Hosomi M, Murakami A, 1999. Growth inhibition of blue-green algae by allelopathic effects of macrophytes. Water Sci. Technol. 39:47-53.

Netten JJC, van Zuidam J, Kostern S, Peeters ETHM, 2011. Differential response to climatic variation of free-floating and submerged macrophytes in ditches. Fresh. Biol. 56:1761-1768.

Nikolić L, Čobanović K, Lazić D, 2007. Nymphoides peltata (Gmel.) Kuntze, Myriophyllum spicatum L. and Ceratophyllum demersum L. biomass dynamics in Lake Provala (the Vojvodina Province, Serbia). Cent. Eur. J. Biol. 2:156-168.

Nõges P, Adrian R, Anneville O, Arvola L, Blenckner T, George G, Jankowski T, Järvinen M, Maberly S, Padisák J, Straile D, Teubner K, Weyhenmeyer GA, 2010. The impact of variations in the climate on seasonal dynamics of phytoplankton, p. 253-274. In: D.G. George (ed.), The impact of climate change on European lakes. Springer, Dordrecht.

Nõges P, Järvet A, Tuvikene L, Nõges T, 1998. The budgets of nitrogen and phosphorus in shallow eutrophic Lake Võrtsjärv. Hydrobiologia 363:219-227.

Nurminen L, 2003. Macrophyte species composition reflecting water quality changes in adjacent water bodies of lake Hiidenvesi, SW Finland. Ann. Bot. Fennici 40:199-208.

Nush EA, 1980. Comparison of different methods for chlorophyll and pheopigment determination, Archiv für Hydrobiologie - Beiheft Ergebnisse der Limnologie 14:14-36.

Ohlendorf C, Bigler C, Goudsmit G-H, Lemcke G, Livingstone DM, Lotter AF, Müller B, Sturm M, 2000. Causes and effects of long periods of ice cover on a remote high Alpine lake. J. Limnol. 59:65-80.

Pace ML, Cole JJ, 2002. Synchronous variation of dissolved organic carbon and color in lakes. Limnol. and Oceanogr. 47:333-342.

Padisák J, Reynolds CS, 2003. Shallow lakes: the absolute, the relative, the functional and the pragmatic. Hydrobiologia 506-509:1-11.

Patalas K, 1984. Mid-summer mixing depths of lakes of different latitudes. Int. Ver. Theor. Angew. Limnol. Verh. Verh. 22:97-102.

Pełechata A, Pełechaty M, Pukacz A, 2015. Winter temperature and shifts in phytoplankton assemblages in a small Charalake. Aquat. Bot. 124:10-18.

Peng S, Piao S, Ciais Ph, Friedlingstein P, Zhou L, Wang T, 2013. Change in snow phenology and its potential feedback to temperature in the Northern Hemisphere over the last three decades. Environ. Res. Lett. 8: 014008.

Reddy KR, Fisher MM, Ivanoff D, 1996. Resuspension and difussive flux of nitrogen and phosphorus in a hypertrophic lake. J. Environ. Qual. 25:363-371. 
Rooney N, Kalff J, 2000. Inter-annual variation in submerged macrophyte community biomass and distribution: the influence of temperature and lake morphometry. Aquat. Bot. 68:321-335.

Salmaso N, 2002. Ecological patterns of phytoplankton assemblages in Lake Garda: seasonal, spatial and historical features. J. Limnol. 61:95-115.

Scheffer M, Hosper SH, Meijer M-L, Moss B, Jeppesen E, 1993. Alternative equilibria in shallow lakes. Trends Ecol. Evol. 8:275-279.

Scheffer M, Van Nes EH, 2007. Shallow lakes theory revisited: various alternative regimes driven by climate, nutrients, depth and lake size. Hydrobiologia 584:455-466.

Schindler DW, Beaty KG, Fee EJ, Cruikshank DR, Debruyn ER, Findlay DL, Linsey GA, Shearer JA, Stainton MP, Turner MA, 1990. Effects of climatic warming on lakes of the central Boreal Forest. Science 250:967-970.

Smal H, Kornijów R, Ligęza S, 2005. The effect of catchment on water quality and eutrophication risk of five shallow lakes (Polesie region, Eastern Poland). Pol. J. Ecol. 53:313-327.

Sokal RR, Rohlf FJ, 1995. Biometry. 3. W.H. Freeman and Company, New York: 887 pp.

Søndergaard M, Jensen JP, Jeppesen E, 2003. Role of sediment and internal loading of phosphorus in shallow lakes. Hydrobiologia 506-509:135-145.

Stefan HG, Fang X, 1993. Model simulations of dissolved oxygen characteristics of Minnesota lakes: past and future. Environ. Manage. 18:73-92.

Straile D, 2000. Meteorological forcing of plankton dynamics in a large and deep continental European lake. Oecol. $122: 44-50$.

Szoszkiewicz K, Zbierska J, Jusik S, Zgoła T, 2010. [Makrofitowa Metoda Oceny Rzek. Podręcznik metodyczny do oceny i klasyfikacji stanu ekologicznego wód płynących w oparciu o rośliny wodne].[Book in Polish]. Bogucki Wyd. Nauk., Poznań: 77 pp.

Tilzer MM, Stambler N, Lovengreen Ch, 1995. The role of phytoplankton in determining the underwater light climate in Lake Constance. Hydrobiologia 316:161-172.

Uchmański J, Szeligiewicz W, 1988. Empirical models for pre- dicting water quality as applied to data on lakes of Poland. Ekol. Pol. 36:285-316.

van Donk E, van de Bund W, 2002. Impact of submerged macrophytes including charophytes on phyto- and zooplankton communities: allelopathy versus other mechanisms. Aquat. Bot. 72: 261-274.

Wallsten M, Forsgren P-O, 1989. The effects of increased water-level on aquatic macrophytes. J. Aquat. Plant Manag. 27:32-37.

Westlake DF, 1965. Theoretical aspects of the comparability of productivity data. Mem. Ist. Ital. Idrobiol. 18:313-322.

Walsby AE, Dubinsky Z, Kromkamp JC, Lehmann C, Schanz F, 2001. The effects of diel changes in photosynthetic coefficients and depth of Planktothrix rubescens on the daily integral of photosynthesis in Lake Zürich. Aquat. Sci. 63:326-349.

Weyhenmeyer GA, Blenckner T, Petterson K, 1999. Changes of the plankton spring outburst related to the North Atlantic Oscillation. Limnol. Oceanogr. 44:1788-1992.

Weyhenmeyer GA, Meilei M, Livingstone DM, 2004. Nonlinear temperature response of lake ice breakup. Geophys. Res. Lett. 31: L07203.

Weyhenmeyer GA, Meilei M, Livingstone DM, 2005. Systematic differences in the trend towards earlier ice-out on Swedish lakes along a latitudinal temperature gradient. Verh. Intern. Verein. Limnol. 29:257-260.

Weyhenmeyer GA, Westöö AK, Willén E, 2008. Increasingly ice-free winters and their effects on water quality in Sweden's largest lakes. Hydrobiologia 599:111-118.

Wilgat T, Michalczyk Z, Turczyński M, Wojciechowski K, 1991. The Łęczna-Włodawa Lakes. Studia Ośr. Dok. Fizjogr. PAN 19:23-140.

Wojciechowska W, Solis M, 2009. [Glony pro- i eukariotyczne jezior Pojezierza Łęczyńsko-Włodawskiego].[Book in Polish]. Wyd. KUL, Lublin: 86 pp.

Zarzycki K, Trzcińska-Tacik H, Różański W, Szeląg Z, Wołek J, Korzeniak U, 2002. Ecological indicator values of vascular plants of Poland. W. Szafer Institute of Botany, Polish Academy of Sciences, Kraków: 183 pp. 